International Journal of Advanced Academic Research | ISSN: 2488-9849

Vol. 7, Issue 3 (March, 2021) | www.ijaar.org

Journal DOI: www.doi.org/10.46654/ij.24889849

\title{
MEDICAL ETHICAL DILEMMA AND EMPLOYEE LOYALTY IN THE PRIVATE HOSPITALS IN BORI-OGONI, RIVERS STATE
}

\author{
Nwizia, Tordumbari Julius \\ tordum4eva@yahoo.com
}

And

\author{
Nwizia, Baribefii Paagolah
}

\begin{abstract}
This study investigates the relationship between medical ethical dilemma and employee loyalty in the private hospitals in Bori-Ogoni, Rivers State.The study used deontological theory of ethics and Alderfer ERG theory of employee loyalty. The quasi-experimental design was used. The population of this study consists of 210 workers in private hospitals in BoriOgoni. The sample size of 140 was determined using Taro Yame sample size determination method. The primary data and secondary sources of data collection were used. The formulated hypotheses were tested using the Spearman Rank Oder Correlation coefficient analysis. The study revealed that is a significant relationship between medical ethical dilemma and medical decisions and employee loyalty in private hospitals in Bori- Ogoni. Therefore, we concluded that there is a strong significant relationship between medical ethical dilemma and medical decisions and employee loyalty in private hospitals in BoriOgoni. We also recommended that private hospitals management should strictly monitor workers medical decision making to ensure that it is in accordance with medical ethics and should also guide employees in dilemma situations in order to retain a loyal medical officer and also achieve generic goals of the organization.
\end{abstract}

Keywords: Medical Ethics, Ethical dilemma and Employee Loyalty 


\subsection{Introduction}

The health sector seriously need loyal employees because the willingness to work under critical conditions and the ability to take decision in line with medical professional ethics and societal moral conduct is highly needed. It is only a loyal health worker that can absolutely obey all medical rules and regulations, treat patients with respect and equity distribution medical resource available in the hospital. It is very important to noted that employee are loyal to the organization and don't actively look for other jobs outside. Employee loyalty is the total submission to the organization. Murali, Poddar and Seema (2017) noted that employee loyalty is the deliberate commitment to remain in the organization even when it demands some personal sacrifices and moral duties. It is the absolute commitment to the activities of an organization. A loyal employee put organizational interest before self interest. Dutot (2004) stated that loyalty is a strong tie that binds a worker to an organization.

Medical ethical paradox is a situation that presents two right decisions. It is critical medical decisions that are sometimes right in the society but unethical in the medical profession. Managing the right of patients, protecting professional ethics and obeying societal moral principles creates much ethical paradox (dilemmas) in the health sector.

\subsection{Statement of the Problem}

Ethical issues in the health sector focus on placing patients' interest before others. In medical professional ethics, fairness, keeping patients' privacy and integrity are the major issues and principles. It is only a loyal health care worker that can withstand dilemmas in the clinic (Weber, 2000). Complex and hypothetical medical decisions influence the level of loyalty among medical officers especially in the private hospitals.

The challenges faced by private hospitals are the inability to attract and retain loyal and ethical health care officers. Medical ethics has been vividly negatively affected by so many factors like the strong needs for personal achievement, the corruption in the drug industry, manipulations of medical results, greed and godfatherism.

This study has not been done using the same variables in the health sector. Based on the above, the study investigates the relationship (if any) between medical ethical dilemma and employee loyalty in the private hospitals in order to fill the gap in the literature.

\subsection{Objectives of the study}

1. To investigate the relationship between medical ethical dilemma and employee loyalty.

2. To determine the relationship between medical ethical decisions and employee loyalty.

\subsection{Research hypotheses}

$\mathrm{H}_{01}$ : There is no significant relationship between medical ethical dilemma and employee loyalty.

$\mathrm{H}_{02}$ : There is no significant relationship between medical ethics decisions and employee loyalty. 
Journal DOI: www.doi.org/10.46654/ij.24889849

\subsection{Review of related literature}

\subsection{The Concept of Medical Ethical Dilemma}

Medical ethics is a system of moral principles that apply value to the practice of clinical medicine. It is the set of values that guides medical profession. The common medical ethics are principle of respect for autonomy, principle of non-male-ficence, principle of justice and principle of beneficences. Medical ethics simply means the application of the care bioethics principles such as autonomy, justice and beneficence. In medical ethics, there is a principle called "not to hand" this means avoiding redundant acts that may worsen the patients' health condition. Schwepker (2011) also identify other medical principles such as principle of being helpful (means considering the patients benefits), the principle to respect self - determination (means demonstrating respect on the patient's decision and approval for medical treatment. Tarinm, Zaim and Torun (2015) noted that ethical issues in medical practices focuses on mentalist approaches that is crucial in making decision and behaviour modification. To them, these mentalist approaches are code of ethics (behaviour that are generally accepted as absolute right or wrong), principlism (using ethical principle to reach the ethical decisions), consequentiality (keep the ethical decisions on the best results and morality, the character of the decision maker as it shows on the behavior). These principles and approaches guide health care workers decision making in all critical situations.

An ethical dilemma is a decision making problem between many moral alternatives. The decision making problem evolves as a result of situational conflict in which obeying one alternative will lead to harming or disobeying another alternative. It is a situation that is uncomfortable which has many moral choices. When facing dilemma in choosing between the best two alternatives and generally acceptable moral principles, health officers are expected to follow medical ethics in order to protect the profession. Dilemma occurs in process of making ethical and moral decisions in line with the professional code of ethics.

Medical ethical paradox or dilemma is a problem in making medical decisions as a result of complex situations in which taking decision will harm other moral decisions. Medical ethical dilemma is real state of affairs that pit two or more medical principles and laws against one another. According to Iyalomhe (2009), medical ethical dilemma refers to the situations in which a health care personnel face many ethical choices and no right answer because each options have major positive or negative consequences. Medical ethics dilemma is a situation in which health care workers being forced to give solutions to problem in interest of patient and the society. It is decision situation in which medical officers choose between life and their professional ethical conduct. The vital point in medical ethical paradox is that the medical personnel must be responsible to make critical decision and do what is right. But in an attempt to do what is right in the society against his/her professional ethical code is the dilemma or paradox that moderate medical ethical decisions. For example, medical doctors are not allowed to render critical services to members of his/her family. The dilemma here is, when the wife is on child labour and there is no other doctor at that point, what will he do? In this situation, the medical doctor is faced with a critical decision making situation which in turn may affect loyalty to the career and the job as well as moral loyalty.

There are two types of medical dilemma:

a. the dilemma whose decision is difficult and

b. dilemma whose decision is tragic. 
A dilemma is difficult when:

1. there is no traditional and mechanical application of medical ethical principles

2. There is no right or wrong answers for a medical case.

3. There is no general agreement on the resolution of a particular medical case.

4. When the remedy of a medical case vividly involves a judgment about good and evil

A dilemma is tragic when: (i) it has to do with the case of life and death (ii) it has to do with case of maternity.

\subsection{Employee loyalty}

Employee loyalty is the high level of workers commitment to the organizational success. Rasput, Singhal and Tiwari (2016) defined employee loyalty as workers being committed to organizational success and behaving as part of the organization. A loyalty employee demonstrates strong citizenship behaviour (membership) to the organization and psychological attachment to the organizational work climate. Solomon (1992) noted that employee loyalty is the willingness to stay with organization and obey the rules and regulations.

Ahmed (2013) identified three dimensions of employee loyalty as emotional loyalty, moral loyalty and continued loyalty. Continued loyalty means the degree to which employee willingness is controlled by the investment worth that can be attained if remain in the organization. Moral loyalty means a sense of commitment of the worker towards remaining with the organization. Emotional loyalty is the individual affection or influential feelings for their job and organization. This study identified the following dimensions of employee loyalty;

Career loyalty: This refers to the willingness to continue with one's career rather than being committed to one's occupation and employer.

Job loyalty: This means submission to employment itself and being committed to work with sense of duty towards job.

Loyalty to organization: This means employee willingness to work in the organization. Employee being committed to the organization rather than their career and profession are seen to be loyal to the organization. It is also the indication to work with the organization in any situation.

\subsection{Empirical Review}

Medical ethics is a standard in which a health care worker's activities may be judge right or wrong. Medical ethics does not varies rather it is the same both in private and public hospital. An employee may be judged due to his/her loyalty and commitment towards the organization and ethical behaviour demonstrated. Muhammed and Venkataran (2016) posit that ethics strengthen employee's loyalty, commitment and motivation. In the same vein, Henn (2009) noted that ethics increases ability of the organization to retain and attract loyal and competent employees. According to Jakhotiya (2003), ethical paradox is a situation that negatively influences the employee level of loyalty. It is only a loyal worker that can vividly work in a situation where a lot of right choices without a clear cut right answer are faced on daily bases. Tarim, Zaim and Torun (2015) revealed that ethical attitude and behaviour of health care workers significantly influence organizational performance. Mabwe (2016) also revealed that 
increase in unethical behaviour among health care workers affects patients, health professionals and insurance companies. Weber (2000) revealed that the need to acquire wealth force medical doctors to act unethical and not being loyal to their organizations.

\subsection{Theoretical Framework}

\section{Deontological theory of ethics}

Broad developed the theory in 1930. He states that moral and ethical action should based on whether the action itself is right or wrong under a formalized rules and laws, rather than based on the consequences of the action. The theory states that workers should adhere to their obligations and duties when involved in decision making and when ethical decision is expected. That is to say, employees will follow his/her obligations for another person or the society because it is ethically correct to uphold one's duty. Broad noted that there is no logical or rationale shortcut for deciding on ethical issues, even in dilemma workers should consider rules and principles that guide their duties and workplace.

\section{Alderfer ERG Theory of Employee Loyalty.}

Alderfer developed ERG theory in 1989. According to him, ERG means

E - $\quad$ Existence needs (the need to stay alive and safe)

$\mathrm{R}$ - $\quad$ Relatedness needs (the need to socialize and relate to others)

G - Growth needs (the need to seek growth and creative).

The theory stated that workers with relatedness needs will be loyal to organization in order to socialize and enlarge his relationship with others. The need to be creative, wholeness and achievement also fuel employee loyalty to a great extent. A worker needs safety and security in the workplace, this made them to be loyal to the organization and obey the rules and regulations that guide their conducts.

\subsection{Research Methodology}

The survey technique of research design was used. The population of the study comprises of 210 health care workers (medical doctors and other health care officers) in private hospitals in Bori - Ogoni.

Table 3.1

\begin{tabular}{|l|l|}
\hline S/N & LIST OF HOSPITALS IN BORI-OGONI \\
\hline 1. & ST. Mercies Healing Hand Hospital \\
\hline 2. & Barido Medical Centre \\
\hline 3. & Recovery Clinic \\
\hline 4. & Leboa Clinic \\
\hline 5. & Inadum Medical centre \\
\hline 6. & Sovereign Clinic \& Maternity \\
\hline 7. & Maxiking Hospital \\
\hline 8. & The Evidence Clinic \\
\hline 9. & Balm Medical \\
\hline 10. & Adenwo Medical Centre \\
\hline 11. & Coset Medical Centre \\
\hline
\end{tabular}

Source: Field Survey, 2021 
The random sampling method was used. The Yaro-Yamen formula was used to determine the sample size for the study.

$$
\begin{aligned}
& n=\frac{N}{1+N(e)^{2}} \\
& n=\frac{210}{1+0.525}
\end{aligned}
$$

Therefore, the sample size is 140 .

$$
\frac{210}{1.5}=140
$$

Data were collected from primary and secondary source. Questionnaire were designed and distributed to 140 respondents. The five points Likert Scale was usedto seal the response which range from strongly agree, agree, fairly agree, disagree and strongly disagree. The Spearman Rank Oder Correlation coefficient analysis was used to test the stated hypotheses.

\subsection{Result and discussion}

\section{Hypothesis 1.}

Ho1: $_{\text {One }}$ There no significant relationship between medical ethical dilemma and employee loyalty in Private Hospitals in Bori-Ogoni.

\begin{tabular}{|c|c|c|c|c|}
\hline \multicolumn{5}{|l|}{ Correlations } \\
\hline & & & $\begin{array}{l}\text { Medical } \\
\text { ethical } \\
\text { paradox }\end{array}$ & $\begin{array}{l}\text { Employe } \\
\text { e } \\
\text { Loyalty }\end{array}$ \\
\hline \multirow[t]{6}{*}{ Spearman's rho } & \multirow[t]{3}{*}{ Medical ethical paradox } & Correlation Coefficient & 1.000 & .425 \\
\hline & & Sig. (2-tailed) & & .000 \\
\hline & & $\mathrm{N}$ & 140 & 140 \\
\hline & \multirow[t]{3}{*}{ Employee Loyalty } & Correlation Coefficient & .425 & 1.000 \\
\hline & & Sig. (2-tailed) & .000 & \\
\hline & & $\mathrm{N}$ & 140 & 140 \\
\hline
\end{tabular}

Table 4.1: Correlation analysis showing the relationship between medical ethical dilemma and employee loyalty.

Source: SPSS data Output (2021).

\section{Hypothese 2.}

$\mathbf{H}_{\mathbf{O} 2}$ : There is no significant relationship between medical decisions and employee loyalty.

\begin{tabular}{|c|c|c|c|c|}
\hline \multicolumn{5}{|l|}{ Correlations } \\
\hline & & & $\begin{array}{l}\text { Medical } \\
\text { decisions }\end{array}$ & $\begin{array}{l}\text { Employe } \\
\text { e } \\
\text { Loyalty }\end{array}$ \\
\hline \multirow[t]{6}{*}{ Spearman's rho } & \multirow[t]{3}{*}{ Medical decisions } & Correlation Coefficient & 1.000 & .544 \\
\hline & & Sig. (2-tailed) & . & .000 \\
\hline & & $\mathrm{N}$ & 140 & 140 \\
\hline & \multirow[t]{3}{*}{ Employee Loyalty } & Correlation Coefficient & .544 & 1.000 \\
\hline & & Sig. (2-tailed) & .000 & . \\
\hline & & $\mathrm{N}$ & 140 & 140 \\
\hline
\end{tabular}

Table 4.2: Correlation analysis showing the relationship between medical decisions and employee loyalty.

Source: SPSS data Output (2021). 
Journal DOI: www.doi.org/10.46654/ij.24889849

\subsection{Discussion of findings}

Table 1 indicates that medical ethical dilemma and employee loyalty correlate at .425 , when the p-value is $0.000<0.05$. This indicated a moderate correlation. Thus, we reject the null hypothesis and accept that there is significant and a strong positive relationship between medical ethical dilemma and employee loyalty. The finding is in line with the work of Jakhotiya (2003) which noted that ethical paradox is a situation that influences the employee level of loyalty. Medical ethical dilemma influences employee loyalty decisions and the extent to which employees are committed to their work, working in line with the profession's rules and regulations and the advancement of organizational goals and objectives.

Table 2 indicates that medical decisions and employee loyalty correlates at .544, when the p-value is $0.000<0.05$. This indicated a strong correlation. Thus, we reject the null hypothesis and accept that the there is significant relationship between medical decisions and employee loyalty. Henn (2009) supported the above finding that ethics decisions increases ability of the organization to retain and attract loyal and competent employees. Some medical decision enables employees to be more loyal to their employer and they work towards retaining their loyalty.

\subsection{Conclusion and recommendations}

An employee who has the willingness to remain in the organization is more likely to display loyal behaviour and work tirelessly to achieve the generic goals and objectives. A loyal workers work in accordance with the workplace ethics and represent the image of the organization to outsides. The vital point in medical ethics paradox is that the medical personnel must be responsible to make critical decision and do what is right. The study revealed that is a significant relationship between medical ethical dilemma and medical decisions and employee loyalty in private Hospitals in Bori- Ogoni. Therefore, we concluded that there is a strong significant relationship between medical ethical dilemma and medical decisions and employee loyalty in private Hospitals in Bori- Ogoni

Based on the findings and conclusion, we recommended that private hospital management should strictly monitor workers medical decision making to ensure that it is in accordance with medical ethics and should also guide employees in dilemma situations in order to retain a loyal medical officer and also achieve generic goals of the organization. 


\section{References}

Ahmad , C.(2013). Factors affecting the organizational loyalty of works in Jordannian Commercial Banks. Interdisciplinary.Journal of Contemporary Research in Business, 4(12): 34-47

Dutot, C. (2004). Contribution to representation of personal loyalty to the company: convergence and divergence element between workers and employers. The case of the workers of two metallurgical industries of the country of Retz. Institute of Business Administration, (8), $31-48$.

Henn, S.H. (2009). Business Ethics: A case study Approach. Cannada, John Wiley \& Son, Inc.

Iyalomhe, G. (2009). Medical ethics and ethical dilemmas in Nigeria. Journal of medicine, 5(6): 56-69

Jakhotiya, N. (2003). Strategic financial management. New Delhi, Vikas Publishing House Ltd.

Mabwe, N. (2016). Impact of ethics on the employee job performance and organizational productivity. Journal of Business Ethics, 8(1) 29 - 38.

Muhammed, G.S., and Venkataram, B.M. (2016). The relationship between workplace ethics and employee attraction, loyalty and financial performance in FDI Companies operating in Adchs Ababa - Ethiopia. International Journal of Applied Research, 2(5): $585-596$.

Murali, S., Poddar, A., and Seema, A. (2017). Employee loyalty, organizational performance: performance evaluation in a critical survey. Journal of Business and Management, 19(8):51-61

Rasput, S., Singhal, M., and Tiwain, S. (2016). Job satisfaction and employee: A study of academicians Asian. Journal of Management, 7(2): 1 -5.

Schwepter, C.H. (2011). Ethical climates relationship to job satisfaction, organizational commitment and turnover intention in the saleforce. Journal of Business research, 54, $39-52$.

Solomon, C.M. (1992). The loyalty factor. Personnel Journal, 3(9): 52 - 62.

Tarim, A., Zaim, C., and Torun, H. (2015). The effects of work ethics practices on hospital performance. Journal of education research, 3(11), 943 - 948.

Webber, T.B. (2000).Tragic dilemmas as the priority of the moral. The journal of ethics, (4), $191-209$. 